\title{
Square Sum Graph Associated with a Sequence of Positive Integers
}

\author{
Reena Sebastian ${ }^{1}$, K.A Germina ${ }^{2}$ \\ ${ }^{I}$ (Department of Mathematics, S.E.S College,Sreekandapuram, India.) \\ ${ }_{2}^{2}$ (School of Mathematical and Physical Sciences, Central University of Kerala, Kasargode, India.)
}

\begin{abstract}
A (p,q)-graph $G$ is said to be square sum, if there exists a bijection $f: V(G) \rightarrow\{0,1,2, . ., p$-1 $\}$ such that the induced function $f^{*}: E(G) \rightarrow N$ defined by $f^{*}(u v)=(f(u))^{2}+(f(v))^{2}$, for every uvE $E(G)$ is injective. In this paper, a recursive construction of infinite families of square sum graphs associate with a sequence of positive integers are studied. That is for any sequence of positive integers (a1,a2,.., an) with ai $\geq 2, i=1,2, . ., n$ we associate some square sum graphs. In particular we obtain the result of level joined planar grid are square sum as the special case.
\end{abstract}

Keywords: Square sum graphs, Level joined planar grid.

\section{Introduction}

If the vertices of the graph are assigned values subject to certain conditions, it is known as graph labeling. A dynamic survey on graph labeling is regularly updated by Gallian[1]. Let $\mathrm{G}=(\mathrm{V}, \mathrm{E})$ be a (p,q)-graph. Unless mentioned otherwise, by a graph we shall mean in this paper a finite, undirected, connected graph without loops or multiple edges. Terms not defined here are used in the sense of Harary[2]. Acharya and Germina defined a square sum labeling of a $(\mathrm{p}, \mathrm{q})$-graph $\mathrm{G}[3,4]$ as follows.

Definition 1.1

A $\$(p, q)$-graph $G$ is said to be square sum, if there exists a bijection $\mathrm{f}: \mathrm{V}(\mathrm{G}) \rightarrow\{0,1,2, . ., \mathrm{p}-1\}$ such that the induced function $\mathrm{f}^{*}: \mathrm{E}(\mathrm{G}) \rightarrow \mathrm{N}$ defined by $\mathrm{f}^{*}(\mathrm{uv})=(\mathrm{f}(\mathrm{u}))^{2}+(\mathrm{f}(\mathrm{v}))^{2}$, for every uve $\mathrm{E}(\mathrm{G})$ is injective.

Here, for any sequence of positive integers $\left(\mathrm{n}_{1}, \mathrm{n}_{2}, \ldots, n \mathrm{nt}\right)$ with $\mathrm{ni} \geq 2, \mathrm{i}=1,2, . . \mathrm{t}$, we associate a square sum graph $\mathrm{H}(<\mathrm{n} 1, \mathrm{n} 2, \ldots, \mathrm{nt}>)$ of order $\mathrm{n} 1+\mathrm{n} 2+\ldots+\mathrm{nt}$ and size $\mathrm{n} 1+\mathrm{n} 2+2 \mathrm{n}_{\mathrm{i}}, 2 \leq \mathrm{i}<\mathrm{t}$. In particular we obtain the result of level joined planar grids are square sum as a special case. Example of square sum graph is shown in Fig 1.
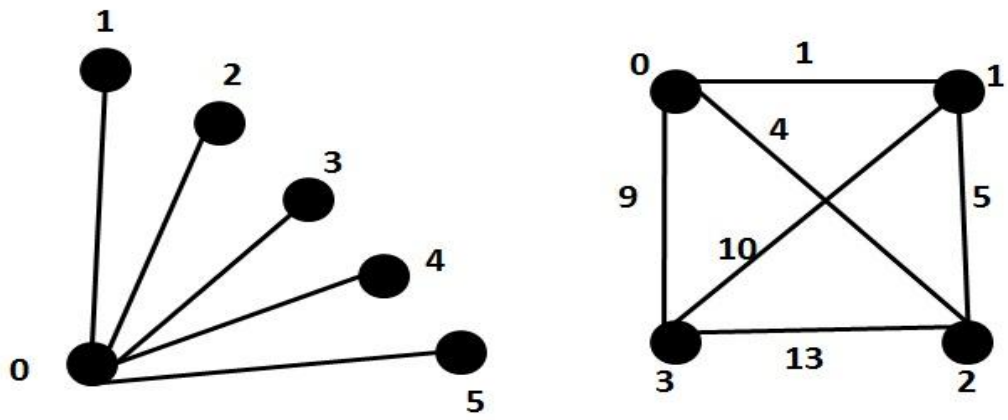

Figure 1

II. Construction of Square Sum Graphs Associated with Sequence of Positive Integers.

Here we present a recursive construction of infinite families of square sum graphs associate with a sequence of positive integers. Let $\mathrm{n} 1, \mathrm{n} 2, \ldots, \mathrm{nt} \in \mathrm{N}^{>1}$, where $\mathrm{N}^{>1}=\{2,3,4, \ldots$.$\} . Let \sigma$ be a sequence of nonzero integers $<\mathrm{n} 1, \mathrm{n} 2, \ldots, \mathrm{nt}>$ of $\mathrm{N}^{>1}$ where $\mathrm{t} \geq 2$. If $\mathrm{n}_{1} \geq 2$, we denote $\mathrm{G}$ as the class of square sum graph constructed by the following way.

When $t=2, \quad G$ consists of the graph of the form $H\left(<n_{1}, n_{2}>\right)$ where $n_{2} \in N^{>1}$. Let $\mathrm{v}(1,1), \mathrm{v}(1,2), \ldots, \mathrm{v}(1, \mathrm{n} 1), \mathrm{v}(2,1), \ldots, \mathrm{v}(2, \mathrm{n} 2)$ be the vertices of $\mathrm{H}\left(<\mathrm{n}_{1}, \mathrm{n}_{2}>\right)$. The graph $\mathrm{H}\left(<\mathrm{n}_{1}, \mathrm{n}_{2}>\right)$ has $\mathrm{n}_{1}+\mathrm{n}_{2}$ vertices with two layers. The top most layer has vertices $\mathrm{v}(1,1), \mathrm{v}(1,2), . ., \mathrm{v}(1, \mathrm{n} 1)$ and the second layer has vertices $\mathrm{v}(2,1), \ldots, \mathrm{v}(2, \mathrm{n} 2)$. The graph $\mathrm{H}<\mathrm{n} 1, \mathrm{n} 2>)$ has edges in the form :

1) If $\mathrm{n} 2 \leq \mathrm{n} 1$, then $\mathrm{E}(\mathrm{H}(<\mathrm{n} 1, \mathrm{n} 2>))=\left\{(\mathrm{v}(1, \mathrm{i}), \mathrm{v}(2, \mathrm{i})),(\mathrm{v}(1, \mathrm{i}+1), \mathrm{v}(2, \mathrm{i})): 1 \leq \mathrm{i} \leq \mathrm{n}_{2}\right\} \mathrm{U}$

$\left\{(\mathrm{v}(1, \mathrm{i}+1), \mathrm{v}(2, \mathrm{n} 2)): \mathrm{n} \_2<\mathrm{i} \leq \mathrm{n}_{1}-1\right\} \cup\{(\mathrm{v}(2,1), \mathrm{v}(2, \mathrm{n} 2))\}$.

2) If $\mathrm{n} 1<\mathrm{n} 2$, then

$\mathrm{E}(\mathrm{H}(\langle\mathrm{n} 1, \mathrm{n} 2\rangle))=\{(\mathrm{v}(1, \mathrm{i}), \mathrm{v}(2, \mathrm{i})),(\mathrm{v}(1, \mathrm{i}), \mathrm{v}(2, \mathrm{i}+1)): 1 \leq \mathrm{i} \leq \mathrm{n} 1\} \mathrm{U}$ 
$\{(\mathrm{v}(1, \mathrm{n} 1), \mathrm{v}(2, \mathrm{i}+1)): \mathrm{n} 1<\mathrm{i} \leq \mathrm{n} 2-1\} \mathrm{U}\{(\mathrm{v}(2,1), \mathrm{v}(2, \mathrm{n} 2))\}$

It is square sum with the following labeling:

$\mathrm{f}(\mathrm{v}(1, \mathrm{i}))=\mathrm{i}-1$ for $1 \leq \mathrm{i} \leq \mathrm{n}_{1}$ and $\mathrm{f}(\mathrm{v}(2, \mathrm{i}))=\mathrm{n} 1+\mathrm{i}-1$ for $1 \leq \mathrm{i} \leq \mathrm{n}_{2}$.

(see Fig. 2 for $\mathrm{H}(<5,3>)$ and $\mathrm{H}(<5,8>)$
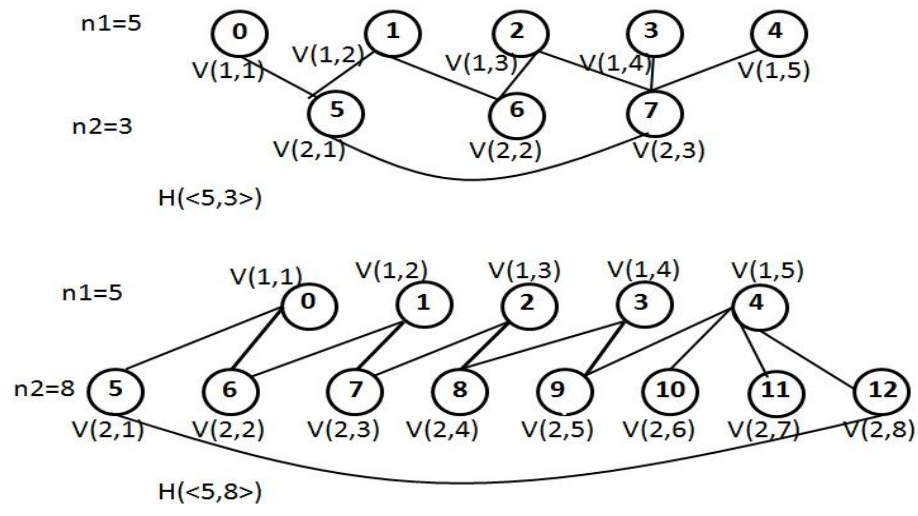

Figure 2 .

When $t=3, \quad G$ consists of the graph of the form $H(<n 1, n 2, n 3>)$ where $n 3 \in N^{>1}$. Let $\mathrm{v}(1,1), \mathrm{v}(1,2), \ldots, \mathrm{v}(1, \mathrm{n} 1), \mathrm{v}(2,1), . ., \mathrm{v}(2, \mathrm{n} 2), \mathrm{v}(3,1), \ldots, \mathrm{v}(3, \mathrm{n} 3)$ be the vertices of $\mathrm{H}(<\mathrm{n} 1, \mathrm{n} 2, \mathrm{n} 3\rangle)$. The graph $\mathrm{H}(<\mathrm{n} 1, \mathrm{n} 2, \mathrm{n} 3>)$ has $\mathrm{n} 1+\mathrm{n} 2+\mathrm{n} 3$ vertices with three layers. The top most layer has vertices $\mathrm{v}(1,1), \mathrm{v}(1,2), \ldots, \mathrm{v}(1, \mathrm{n} 1)$, the second layer has vertices $\mathrm{v}(2,1), \ldots, \mathrm{v}(2, \mathrm{n} 2)$ and third layer has vertices $\mathrm{v}(3,1), \ldots, \mathrm{v}(3, \mathrm{n} 3)$. We arrange the vertices of $\mathrm{H}(<\mathrm{n} 1, \mathrm{n} 2, \mathrm{n} 3>)$ layer by layer and from left to right as follows.

a) The top most layer is $\mathrm{H}(<\mathrm{n} 1, \mathrm{n} 2>)$

b) The second layer has vertices $\mathrm{v}(3,1), \ldots, \mathrm{v}(3, \mathrm{n} 3)$. The graph $\mathrm{H}(<\mathrm{n} 1, \mathrm{n} 2, \mathrm{n} 3>)$ has edges of the form :

1). If $\mathrm{n} 3 \leq \mathrm{n} 2$, then $\mathrm{E}(\mathrm{H}(<\mathrm{n} 1, \mathrm{n} 2, \mathrm{n} 3>))=\mathrm{E}(\mathrm{H}(<\mathrm{n} 1, \mathrm{n} 2>)) \cup\{(\mathrm{v}(2, \mathrm{i}), \mathrm{v}(3, \mathrm{i})),(\mathrm{v}(2, \mathrm{i}+1), \mathrm{v}(3, \mathrm{i})): 1 \leq \mathrm{i} \leq \mathrm{n} 3\} \cup$

$\{(\mathrm{v}(2, \mathrm{i}+1), \mathrm{v}(3, \mathrm{n} 3)): \mathrm{n} 3<\mathrm{i} \leq \mathrm{n} 2-1\} \cup(\mathrm{v}(3,1), \mathrm{v}(3, \mathrm{n} 3))\}$.

$2)$ If $\mathrm{n} 2<\mathrm{n} 3$, then $\mathrm{E}(\mathrm{H}(<\mathrm{n} 1, \mathrm{n} 2, \mathrm{n} 3>))=\mathrm{E}(\mathrm{H}(<\mathrm{n} 1, \mathrm{n} 2>)) \quad \mathrm{U}\{(\mathrm{v}(2, \mathrm{i}), \mathrm{v}(3, \mathrm{i})),(\mathrm{v}(2, \mathrm{i}), \mathrm{v}(3, \mathrm{i}+1)): \quad 1 \leq \mathrm{i} \leq$ $\left.\mathrm{n} \_2\right\} \cup\{(\mathrm{v}(2, \mathrm{n} 2), \mathrm{v}(3, \mathrm{i}+1)): \mathrm{n} 2<\mathrm{i} \leq \mathrm{n} 3-1\} \cup\{(\mathrm{v}(3,1), \mathrm{v}(3, \mathrm{n} 3))\}$.

We can extend the labeling of $\mathrm{f}$ in $\mathrm{G}=\mathrm{H}(<\mathrm{n} 1, \mathrm{n} 2>)$ to $\mathrm{H}(<\mathrm{n} 1, \mathrm{n} 2, \mathrm{n} 3>)$ by defining

$\mathrm{f}(\mathrm{v}(3, \mathrm{i}))=\mathrm{n} 1+\mathrm{n} 2+\mathrm{i}-1$ for $1 \leq \mathrm{i} \leq \mathrm{n} 3$. With the above defined vertex labeling no two of the edge labels are same as the edge labels are in an increasing order.

(See Fig.3 and Fig.4 for $\mathrm{H}(<5,3,4>)$ and $\mathrm{H}(<5,8,6>)$.

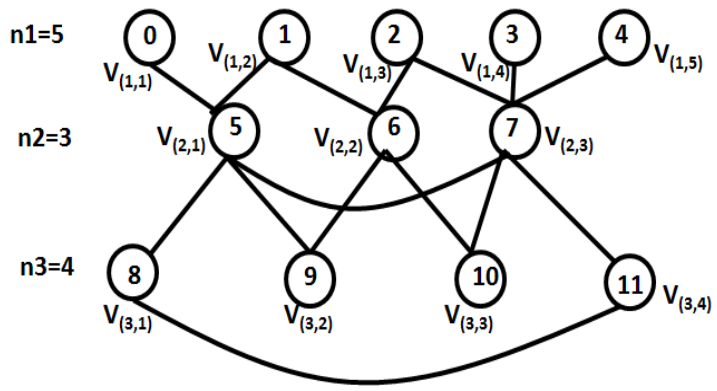

Figure 3

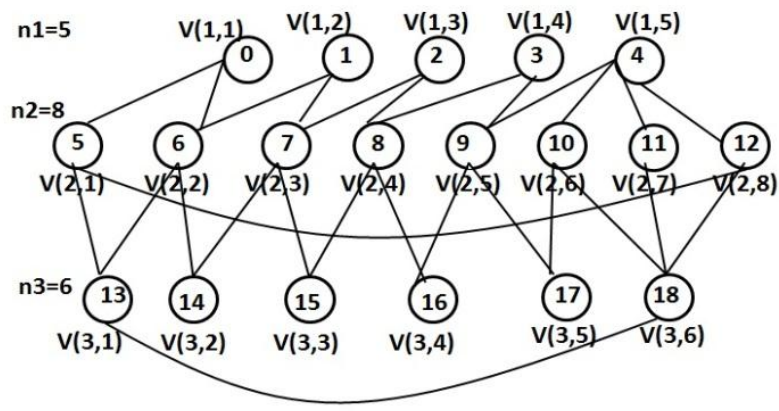

$H(<5,8,6>)$

Figure 4 


\section{Induction Hypothesis}

Assume that $\mathrm{H}(<\mathrm{n} 1, \mathrm{n} 2, \ldots, \mathrm{nt}>)$ is square sum. For any $\mathrm{n}\{\mathrm{t}+1\} \in \mathrm{N}^{>1}$, let $\mathrm{W}$ be the graph with $\mathrm{V}(\mathrm{W})=\{\mathrm{v}(\mathrm{t}+1,1), \mathrm{v}(\mathrm{t}+1,2), . ., \mathrm{v}(\mathrm{t}+1, \mathrm{n}\{\mathrm{t}+1\})\}$ and $\mathrm{E}(\mathrm{W})=\{(\mathrm{v}(\mathrm{t}+1,1),(\mathrm{v}(\mathrm{t}+1, \mathrm{n}\{\mathrm{t}+1\})\}$. we can construct a new graph $\mathrm{H}(<\mathrm{n} 1, \mathrm{n} 2, . ., \mathrm{n}\{\mathrm{t}+1\}>)$ as follows: The graph $\mathrm{H}(<\mathrm{n} 1, \mathrm{n} 2, . ., \mathrm{n}\{\mathrm{t}+1\}>)$ has $\mathrm{n} 1+\mathrm{n} 2+\ldots+\mathrm{nt}+\mathrm{n}\{\mathrm{t}+1\}$ vertices. $\mathrm{V}(\mathrm{H}(<\mathrm{n} 1, \mathrm{n} 2, \ldots, \mathrm{n}\{\mathrm{t}+1\}>))=\mathrm{V}(\mathrm{H}(<\mathrm{n} 1, \mathrm{n} 2, . ., \mathrm{nt}>)) \cup\{\mathrm{v}(\mathrm{t}+1,1), \ldots, \mathrm{v}(\mathrm{t}+1, \mathrm{n}\{\mathrm{t}+1\})\}$. We arrange the vertices of $\mathrm{H}(<\mathrm{n} 1, \mathrm{n} 2, \ldots, \mathrm{n}\{\mathrm{t}+1\}>)$ layer by layer and from left to right as follows:

a) the top most layer is $\mathrm{H}(<\mathrm{n} 1, \mathrm{n} 2, \ldots, \mathrm{nt}>)$,

b) the second layer has vertices $v(t+1,1), \ldots, v(t+1, n\{t+1\})$,

The graph $\mathrm{H}(<\mathrm{n} 1, \mathrm{n} 2, . ., \mathrm{n}\{\mathrm{t}+1\}>)$ has edges of the form :

1). If $\mathrm{n}\{\mathrm{t}+1\} \leq \mathrm{nt}$, then $\mathrm{E}(\mathrm{H}(<\mathrm{n} 1, \mathrm{n} 2, \ldots, \mathrm{n}\{\mathrm{t}+1\}>))=\mathrm{E}(\mathrm{H}(<\mathrm{n} 1, \mathrm{n} 2, \ldots, \mathrm{nt}>)) \cup \mathrm{E}(\mathrm{W}) \cup$

$\{(\mathrm{v}(\mathrm{t}, \mathrm{i}), \mathrm{v}(\mathrm{t}+1, \mathrm{i})),(\mathrm{v}(\mathrm{t}, \mathrm{i}+1), \mathrm{v}(\mathrm{t}+1, \mathrm{i})): \mathrm{i}=1,2, \ldots, \mathrm{n}\{\mathrm{t}+1\}\} \cup\{\mathrm{v}(\mathrm{t}, \mathrm{i}+1), \mathrm{v}(\mathrm{t}+1, \mathrm{n}\{\mathrm{t}+1\})): \mathrm{n}\{\mathrm{t}+1\}<\mathrm{i} \leq \mathrm{nt}-1\}$.

2). If $n t<n\{t+1\}$, then $E(H(<n 1, n 2, . ., n\{t+1\}>))=E(H(<n 1, n 2, . ., n t>)) \cup E(W) \cup$

$\{\mathrm{v}(\mathrm{t}, \mathrm{i}), \mathrm{v}(\mathrm{t}+1, \mathrm{i})),(\mathrm{v}(\mathrm{t}, \mathrm{i}), \mathrm{v}(\mathrm{t}+1, \mathrm{i}+1)): \mathrm{i}=1,2, \ldots, \mathrm{nt}\} \cup\{\mathrm{v}(\mathrm{t}, \mathrm{nt}), \mathrm{v}(\mathrm{t}+1, \mathrm{i}+1): \mathrm{nt}<\mathrm{i} \leq \mathrm{n}\{\mathrm{t}+1\}-1\}$. We can extend the labeling of $\mathrm{f}$ in $\mathrm{G}=\mathrm{H}(\langle\mathrm{n} 1, \mathrm{n} 2, \ldots, \mathrm{nt}\rangle)$ to $\mathrm{H}(\langle\mathrm{n} 1, \mathrm{n} 2, \ldots, \mathrm{n}\{\mathrm{t}+1\}>)$ by defining $\mathrm{f}(\mathrm{v}(\mathrm{t}+1, \mathrm{i}))=\mathrm{n} 1+\mathrm{n} 2+\ldots+\mathrm{nt}+\mathrm{i}-1$ for $\mathrm{i}=1,2, \ldots, \mathrm{n}\{\mathrm{t}+1\}$.

\section{Theorem 2.1}

The graph $\mathrm{H}(\langle\mathrm{n} 1, \mathrm{n} 2, . ., \mathrm{n}\{\mathrm{t}+1\}\rangle)$ is square sum.

Proof

In fact $\mathrm{H}(<\mathrm{n} 1, \mathrm{n} 2, \ldots, \mathrm{n}\{\mathrm{t}+1\}>)$ is $\mathrm{H}(<\mathrm{n} 1, \mathrm{n} 2, \ldots, \mathrm{nt}>) \cup \ell \cup \mathrm{W}$, where

1. $\ell=\{(\mathrm{v}\{(\mathrm{t}, \mathrm{i})\}, \mathrm{v}\{(\mathrm{t}+1, \mathrm{i})\}),(\mathrm{v}\{(\mathrm{t}, \mathrm{i}+1)\}, \mathrm{v}\{(\mathrm{t}+1, \mathrm{i})\}): \mathrm{i}=1,2, . ., \mathrm{n}\{\mathrm{t}+1\}\} \cup\{(\mathrm{v}\{(\mathrm{t}, \mathrm{i}+1)\}, \mathrm{v}\{(\mathrm{t}+1, \mathrm{n}\{\mathrm{t}+1\})\}): \mathrm{n}\{\mathrm{t}+1\}<\mathrm{i} \leq$ nt-1 $\}$, if $n\{t+1\} \leq n \_t$.

2. $\ell=\{(\mathrm{v}\{(\mathrm{t}, \mathrm{i})\}, \mathrm{v}\{(\mathrm{t}+1, \mathrm{i})\}),(\mathrm{v}\{(\mathrm{t}, \mathrm{i})\}, \mathrm{v}\{(\mathrm{t}+1, \mathrm{i}+1)\}): \mathrm{i}=1,2, . . \mathrm{nt}\} \cup\{(\mathrm{v}\{(\mathrm{t}, \mathrm{nt})\}, \mathrm{v}\{(\mathrm{t}+1, \mathrm{i}+1)\}): \mathrm{nt}<\mathrm{i} \leq \mathrm{n}\{\mathrm{t}+1\}-1\}$, if $\mathrm{nt}<\mathrm{n}\{\mathrm{t}+1\}$.

Since labels of $v\{(t, i)\}, 1 \leq \mathrm{i} \leq \mathrm{nt}$ are in increasing order and strictly less than the labels of $\mathrm{v}\{(\mathrm{t}+1, \mathrm{i})\}, 1 \leq \mathrm{i} \leq$ $\mathrm{n}\{\mathrm{t}+1\}, \mathrm{E}(\mathrm{H}(<\mathrm{n} 1, \mathrm{n} 2, \ldots, \mathrm{nt}>)) \cup \ell \cup \mathrm{E}(\mathrm{W})$ can be arranged in strictly increasing order. Hence no two of the edge labels are same.

Remark 2.2

In the sequence $\langle\mathrm{n} 1, \mathrm{n} 2, \ldots, \mathrm{nt}\rangle,, \mathrm{ni} \geq 2, \mathrm{i}=1,2, . ., \mathrm{t}$ of $\mathrm{H}(\langle\mathrm{n} 1, \mathrm{n} 2, \ldots, \mathrm{nt}\rangle)$, if we change the order of the sequence, then the graphs are isomorphic.The only nonisomorphic classes of graph is one with at least one of these ni=1.

Now we consider the sequence $\sigma$ on $\mathrm{N}=\{1,2, .$.$\} with the following property. \sigma=(\langle 1, \mathrm{n} 1, \mathrm{n} 2, . ., \mathrm{nt}\rangle)$ where $\mathrm{n} 1, \mathrm{n} 2, \ldots, \mathrm{nt}$ in $\mathrm{N}^{>1}$. We construct a new graph $\left.\mathrm{H}^{*}(<\mathrm{n} 1, \mathrm{n} 2, \ldots, \mathrm{nt}\rangle\right)$ as follows. The graph $\left.\mathrm{H}(<\mathrm{n} 1, \mathrm{n} 2, \ldots, \mathrm{nt}\rangle\right)$ has $\mathrm{n} 1+\mathrm{n} 2+\ldots+\mathrm{nt}$ vertices in $\mathrm{G}$.

$\mathrm{V}\left(\mathrm{H}^{*}(<\mathrm{n} 1, \mathrm{n} 2, . ., \mathrm{nt}>)\right)=\mathrm{V}(\mathrm{H}(<\mathrm{n} 1, \mathrm{n} 2, . ., \mathrm{nt}>)) \cup\{\mathrm{z}\}$.

We arrange the vertices of $\mathrm{H}(<\mathrm{n} 1, \mathrm{n} 2, . ., \mathrm{nt}>)$ layer by layer and from left to right and label the vertices as before. The lower layer has vertex $\mathrm{z}$. The graph $\left.\mathrm{H}^{*}(<\mathrm{n} 1, \mathrm{n} 2, \ldots, \mathrm{nt}\rangle\right)$ has edges in the form:

$\left.\mathrm{E}\left(\mathrm{H}^{*}(<\mathrm{n} 1, \mathrm{n} 2, \ldots, \mathrm{nt}>)\right)=\mathrm{E}(\mathrm{H}(<\mathrm{n} 1, \mathrm{n} 2, \ldots, \mathrm{nt}>)) \cup\{(\mathrm{v}(\mathrm{t}, \mathrm{i}), \mathrm{z})): \mathrm{i}=1,2, . ., \mathrm{nt}\right\}$. We can extend the labeling of $\mathrm{f}$ in $\mathrm{G}=\mathrm{H}(<\mathrm{n} 1, \mathrm{n} 2, \ldots, \mathrm{nt}>)$ to $\mathrm{H}^{*}(<\mathrm{n} 1, \mathrm{n} 2, \ldots, \mathrm{nt}>)$ by defining $\mathrm{f}(\mathrm{z})=\mathrm{n} 1+\mathrm{n} 2+\ldots+\mathrm{nt}$.

With the above labeling, no two of the edge labels are same as the edge labels are in strictly increasing order. Fig. 5 depicts $H^{*}(<5,3>)$

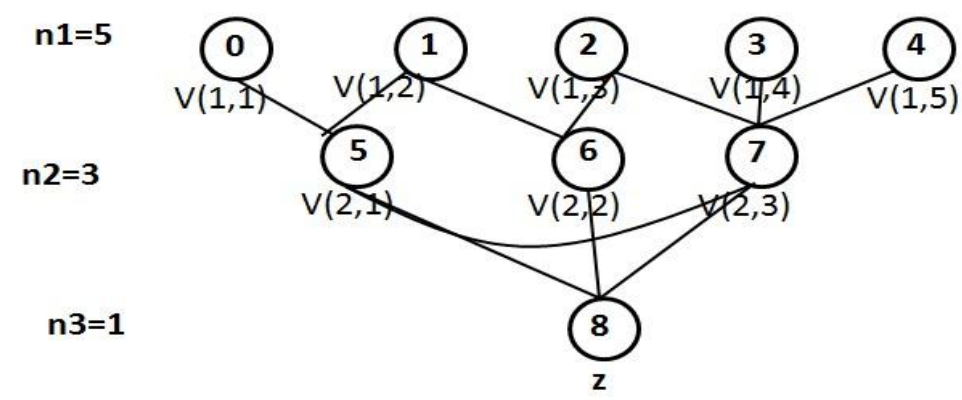

Figure 5

Hence we have the following theorem.

Theorem 2.3

The graph $\left.\mathrm{H}^{*}(<\mathrm{n} 1, \mathrm{n} 2, \ldots, \mathrm{nt}\rangle\right)$ is square sum.

Dually we can construct a new graph $* \mathrm{H}(<\mathrm{n} 1, \mathrm{n} 2, . ., \mathrm{nt}\rangle)$ as follows. 
$\mathrm{V}\left({ }^{*} \mathrm{H}(<\mathrm{n} 1, \mathrm{n} 2, \ldots, n t>)\right)=\{\mathrm{u}\} \cup \mathrm{V}(\mathrm{H}(<\mathrm{n} 1, \mathrm{n} 2, . ., \mathrm{nt}>))$. The upper layer has vertex $\mathrm{u}$. We arrange the vertices of $\mathrm{H}(<\mathrm{n} 1, \mathrm{n} 2, . ., \mathrm{nt}>)$ layer by layer and from left to right and label the vertices as before. The graph ${ }^{*} \mathrm{H}(<\mathrm{n} 1, \mathrm{n} 2, . ., \mathrm{nt}>)$ has edges in the form :

$\mathrm{E}(* \mathrm{H}(<\mathrm{n} 1, \mathrm{n} 2, \ldots, \mathrm{nt}>))=\{(\mathrm{u}, \mathrm{v}(1, \mathrm{i})): \mathrm{i}=1,2, . ., \mathrm{n} 1\} \cup \mathrm{E}(\mathrm{H}(<\mathrm{n} 1, \mathrm{n} 2, . ., \mathrm{nt}>))$. With the above labeling, no two of the edge labels are same as the edge labels are in increasing order. We illustrate $* \mathrm{H}(<3,3>),{ }^{*} \mathrm{H}(<4,4>)$ in Fig. 6.
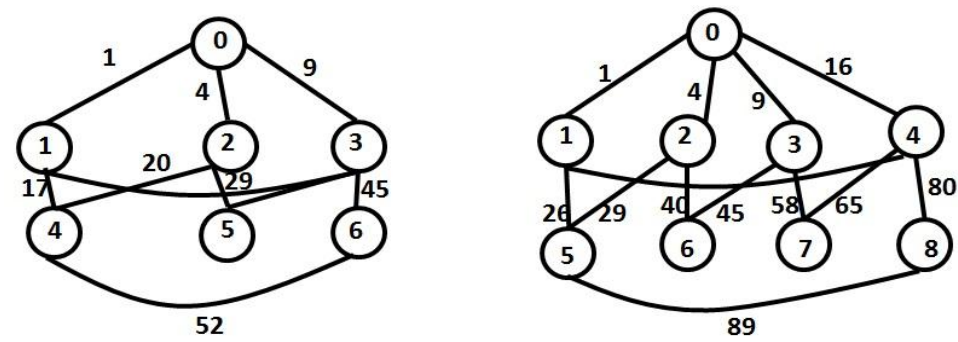

Figure 6

In fact, we have the following theorem.

Theorem 2.4

The graph $* \mathrm{H}(<\mathrm{n} 1, \mathrm{n} 2, . ., \mathrm{nt}>)$ is square sum

We illustrate $* \mathrm{H}(<2,3,2>), \mathrm{H}(<2,3,4,3>)$ in Fig. 7 .
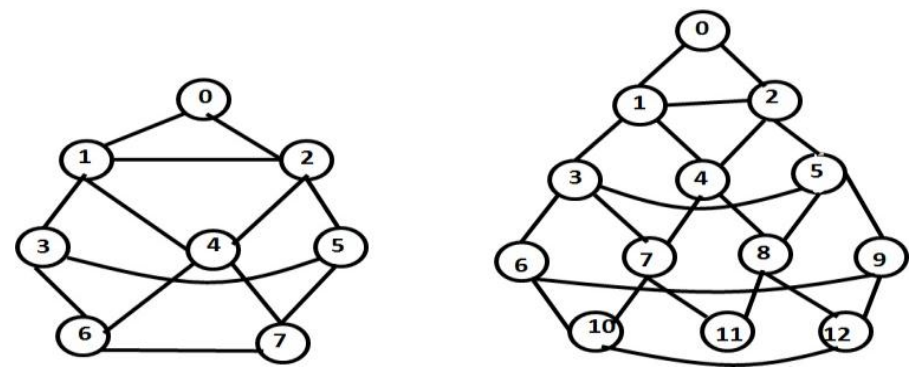

Figure 7

Definition 2.5

Level joined planar grids [5]: Let $u$ be a vertex of $\mathrm{Pm} \times \mathrm{Pn}$ such that $\operatorname{deg}(\mathrm{u})=2$. Introduce an edge between every pair of distinct vertices $\mathrm{v}, \mathrm{w}$ with $\operatorname{deg}(\mathrm{v}), \operatorname{deg}(\mathrm{w}) \neq 4$, if $\mathrm{d}(\mathrm{u}, \mathrm{v})=\mathrm{d}(\mathrm{u}, \mathrm{w})$, where $\mathrm{d}(\mathrm{u}, \mathrm{v})$ is the distance between $\mathrm{u}$ and $\mathrm{v}$. The graph so obtained is defined as level joined planar grid and is denoted by $\mathrm{LJ}_{\mathrm{m}, \mathrm{n}}$. $\mathrm{An}_{\mathrm{n}}$ example of $\mathrm{LJ}_{4,5}$ is illustrated in Fig 8.

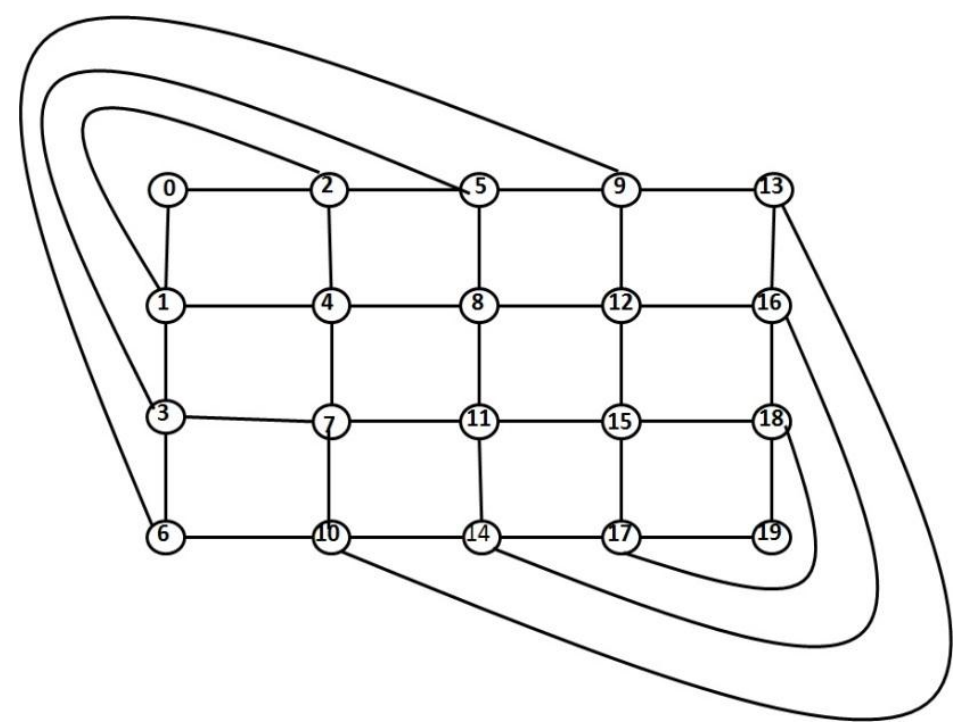

Figure 8 
We observe that $\mathrm{LJ}_{\mathrm{m}, \mathrm{n}}$ is the graph $* \mathrm{H}^{*}<2,3, \ldots, \mathrm{m}, .$. (n-m)times $\mathrm{m}, \mathrm{m}-1, \mathrm{~m}-2, . ., 2>$. In Figure $8, \mathrm{~m}=4$ and $\mathrm{n}=5$, and it is $* \mathrm{H}^{*}<2,3,4,4,3,2>$. Hence by theorem 2.3 we have the following.

Corollary 2.6

The graph $\mathrm{LJ}_{\mathrm{m}, \mathrm{n}}$ is square sum.

\section{Conclusion}

Square sum graphs were studied in $[4,6,7]$. Our paper produces infinitely many square sum graphs.

\section{References}

[1]. J.A.Gallian, A dynamic survey of graph labeling, The Electronic Journal of Combinatorics (DS6),2005

[2]. F. Harary, Itextbf\{Graph Theory\}, Addison-Wesley Pub. Comp., Reading, Massachusetts, 1969.

[3]. B.D.Acharya, Inewblock \{lem Personal Communication\}, Inewblock September 2011.

[4]. Ajitha V, lemph\{Studies in Graph Theory-Labeling of Graphs\}, Ph D thesis (2007), Kannur Univeristy, Kannur.

[5]. B.D.Acharya and Hegde, lemph\{Strongly Multiplicative graphs\}, Discrete Mathematics 93(1991),123-129.

[6]. Germina K.A and Reena Sebastian,(2013). Further results on square sum graphs, International Mathematical Forum,(8) 47-57.

[7]. . Reena Sebastian and Germina K.A, Maximal square sum subgraph of a complete graph, accepted. 